\title{
Art and the Gregorian Reform: Saints Peter and Clement in the Church of San Marco at Venice
}

\author{
Lesley Jessop
}

Volume 32, numéro 1-2, 2007

URI : https://id.erudit.org/iderudit/1069591ar

DOI : https://doi.org/10.7202/1069591ar

Aller au sommaire du numéro

\section{Éditeur(s)}

UAAC-AAUC (University Art Association of Canada | Association d'art des universités du Canada)

\section{ISSN}

0315-9906 (imprimé)

1918-4778 (numérique)

Découvrir la revue

Citer cet article

Jessop, L. (2007). Art and the Gregorian Reform: Saints Peter and Clement in the Church of San Marco at Venice. RACAR : Revue d'art canadienne / Canadian Art Review, 32(1-2), 24-34. https://doi.org/10.7202/1069591ar

\section{Résumé de l'article}

Dans la basilique Saint-Marc, à Venise, des mosaïques illustrant des événements dans la vie de saint Pierre et de saint Clément ornent les murs nord et sud des choeurs, au niveau de la galerie. Des recherches académiques antérieures ont porté sur le style, l'iconographie et la relation des mosaïques aux cycles consacrés à saint Marc, situés dans les voûtes, mais quelques questions fondamentales demeurent. Pierre est le saint titulaire du choeur nord ; il est souvent jumelé à Paul, et l'on s'entend pour dire que les deux choeurs ont été conçus pour aller ensemble. Pourquoi, donc, le choeur sud a-t-il été consacré à Clément ? Et quels sont les critères qui ont régi la combinaison de scènes montrant l'arrestation et l'évasion de prison de Pierre dans la chapelle nord, et Clément en train de célébrer la messe, accompagné de la tentative de capture de Sisinnius au sud ? Pour répondre à ces questions, le présent essai interprète les mosaïques dans le contexte des activités politiques et ecclésiastiques des Vénitiens dans la première moitié du XII ${ }^{\mathrm{e}}$ siècle. Nous en arrivons à la conclusion que les mosaïques sont le reflet d'un ensemble de préoccupations étroitement liées qui animaient alors les Vénitiens : leur intérêt pour la succession, l'influence du mouvement de la réforme grégorienne et la participation du doge Domenico Michiel (1118-29) à la croisade réussie du pape Calixte II (1119-24).
Tous droits réservés (C) UAAC-AAUC (University Art Association of Canada | Association d'art des universités du Canada), 2007
Ce document est protégé par la loi sur le droit d'auteur. L'utilisation des services d'Érudit (y compris la reproduction) est assujettie à sa politique d'utilisation que vous pouvez consulter en ligne.

https://apropos.erudit.org/fr/usagers/politique-dutilisation/ 


\title{
Art and the Gregorian Reform: Saints Peter and Clement in the Church of San Marco at Venice
}

\author{
LESLEY JESSOP, INDEPENDENT SCHOLAR
}

\begin{abstract}
Résumé
Dans la basilique Saint-Marc, à Venise, des mosaïques illustrant des événements dans la vie de saint Pierre et de saint Clément ornent les murs nord et sud des chœurs, au niveau de la galerie. Des recherches académiques antérieures ont porté sur le style, l'iconographie et la relation des mosaïques aux cycles consacrés à saint Marc, situés dans les voûtes, mais quelques questions fondamentales demeurent. Pierre est le saint titulaire du chœur nord ; il est souvent jumelé à Paul, et l'on s'entend pour dire que les deux chœurs ont été conçus pour aller ensemble. Pourquoi, donc, le chœur sud a-t-il été consacré à Clément? Et quels sont les critères qui ont régi la combinaison de scènes montrant l'arrestation et l'évasion de prison de Pierre dans la
\end{abstract}

chapelle nord, et Clément en train de célébrer la messe, accompagné de la tentative de capture de Sisinnius au sud? Pour répondre à ces questions, le présent essai interprète les mosaïques dans le contexte des activités politiques et ecclésiastiques des Vénitiens dans la première moitié du $X \|^{e}$ siècle. Nous en arrivons à la conclusion que les mosaïques sont le reflet d'un ensemble de préoccupations étroitement liées qui animaient alors les Vénitiens: leur intérêt pour la succession, l'influence du mouvement de la réforme grégorienne et la participation du doge Domenico Michiel (1118-29) à la croisade réussie du pape Calixte II (1119-24).
$\mathrm{T}$ he north and south choir chapels of the church of San Marco, at Venice, more popularly known as the Cappella di San Pietro and the Cappella di San Clemente, contain relics and the portraits of their titular saints on the ground floor, ${ }^{1}$ while abbreviated cycles depicting events from their lives adorn the north and south end walls at the gallery level (figs. 1-4). As they form only a small part of the extensively decorated church, and are partially hidden behind the church organ, the narrative images have not attracted much attention. ${ }^{2}$ In his magisterial work on San Marco, Otto Demus briefly discussed their style and iconography, proposing that the mosaics were produced in the first half of the twelfth century ${ }^{3}$ and, more recently, Bruno Bertoli has examined the images in the context of the Marcian narratives located in the vaults above. ${ }^{4}$ The work of Demus and Bertoli has made an important contribution to our understanding of the mosaics, but several questions remain.

Peter is normally coupled with Paul. Why, therefore, was the south choir chapel dedicated to Clement? Bertoli justified this anomaly by relating Clement's presence to his role as Peter's successor to the papal throne. Yet, throughout the Middle Ages, in Venice and elsewhere, Clement was not usually regarded as Peter's immediate successor, but as either the third or fourth bishop of Rome. ${ }^{5}$ Bertoli also noted that Peter and Clement were connected to Mark via Egypt, as Clement converted in Alexandria prior to meeting Peter, and Peter instructed Mark to go to Alexandria. Nevertheless, numerous saints have ties to Egypt, which makes Clement far from unique in this regard. The final link that justifies Clement's inclusion is still missing. Demus also described the selection of narrative scenes as "arbitrary and unusual." 6 Medieval iconographers were rarely, if ever, whimsical. Indeed, the mosaics of Saints Peter and Clement demonstrate how easily the original significance of images can be forgotten once their social contexts have changed. ${ }^{7}$

In order to improve out understanding of the mosaics, the aim of this paper is to examine the images within the context of the political and ecclesiastical activities of the Venetians in the twelfth century. As a result, the seemingly unusual pairing of Saints Peter and Clement, and the curious choice of scenes, will be shown to reflect a group of inter-related concerns that preoccupied the Venetians in the early twelfth century: their interest in succession, the influence of the Gregorian Reform movement, and the participation of Doge Domenico Michiel (111829) in the successful crusade of Pope Callixtus II (1119-24).

The mosaics and details of their restoration have been thoroughly described by Demus, ${ }^{8}$ so that only the salient points will be repeated here. In the north choir chapel, directly below the images of Mark's martyrdom and burial, the mosaics tell the story of Peter's arrest by King Herod followed by his escape from prison (Acts 12:3-11). After his arrest Peter was tied down with chains and guarded by soldiers who slept on either side of him. The night before his trial an angel appeared to Peter, woke him, and told him to get up. Miraculously, Peter's chains fell off. In the company of the angel, and without waking any of the guards, Peter walked out of prison and through the city gate.

In San Marco the narrative reads in a west-east direction (from left to right) on the north wall of the choir chapel, beginning with the soldiers bringing Peter before Herod (fig. 1). This is followed by Peter's escape from prison: a group of soldiers stand outside the prison building, while an angel leads Peter out of prison (fig. 2). Unfortunately, the mosaics on the eastern part of the wall are barely visible from the ground, as they are in a poor state of preservation and partially hidden behind the church's organ. An inscription above all the scenes reads: HIC IVBET; HIC CAPITVR; VIGILANT; EXIT; CITAT ISTE (this man orders; this man is seized; they are vigilant; he leaves; that one summons).

In the south choir chapel, beneath the story of Mark's relics being shipped to Venice, mosaics illustrate two episodes from 
Figure Ia, Ib. Arrest of Saint Peter, north choir chapel, Church of San Marco, Venice (Photos: Osvaldo Böhm).

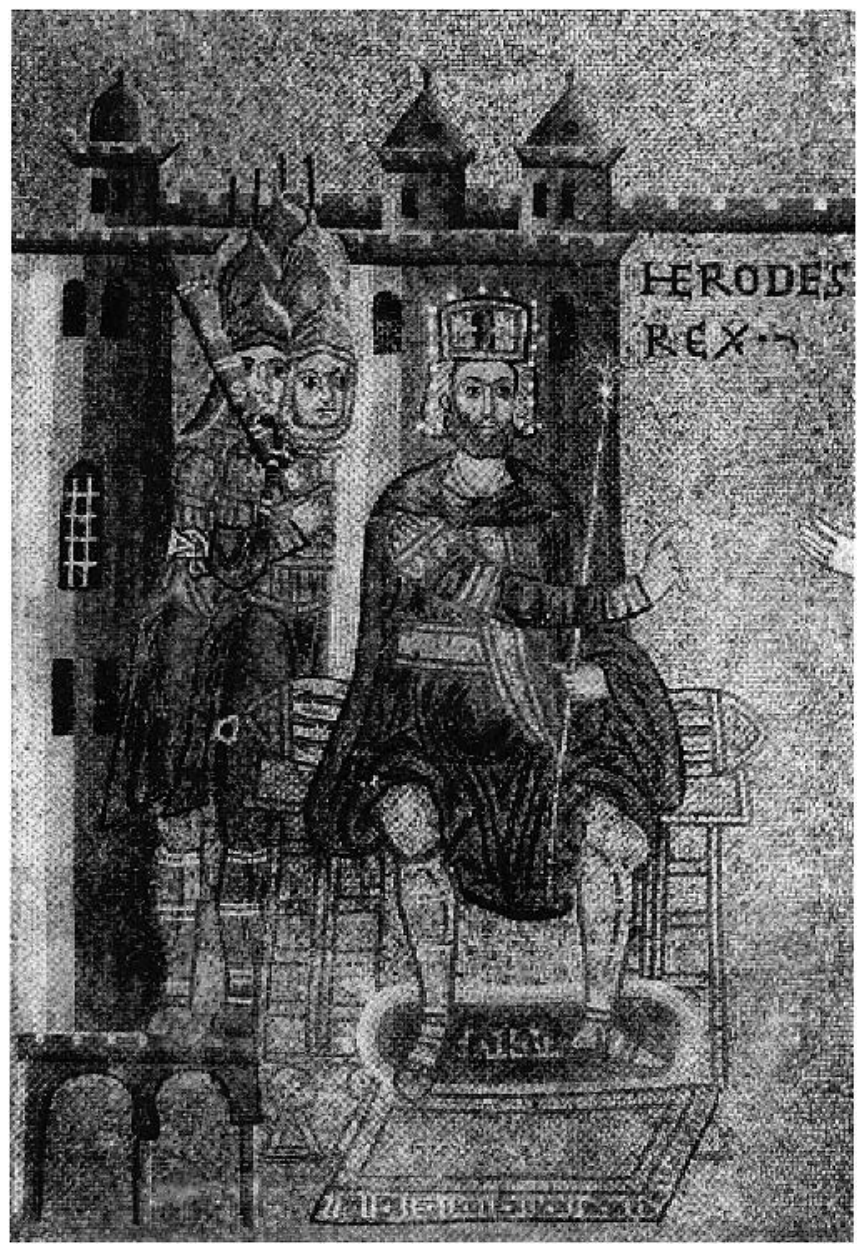

the legend of Clement's conversion of an aristocratic couple named Theodora and Sisinnius. After Theodora's conversion to Christianity, her husband Sisinnius - who was still pagan became suspicious of his wife's absences from the house. One day he followed her into church, stumbled into a service in progress, and was struck blind and deaf. His servants tried to lead him outside, but were unable to find the door. Theodora noticed their plight and through the force of her prayers, her husband was able to find the exit. Clement later came to the house to restore Sisinnius's sight and hearing. Once Sisinnius's sight had been restored and he saw Clement standing next to his wife, he became suspicious of Clement's role in his sudden blindness. He ordered his servants to tie up Clement. Instead, the servants tricked him by bundling up a pillar and some stones, and Clement was able to escape. The written legend ends with Clement's conversion of Sisinnius. ${ }^{9}$

In San Marco the story runs in a west-east direction (from right to left) on the south wall of the choir chapel. At an unknown date, the lower third of the mosaics was removed and partially replaced with a vegetal border. The first scene is set

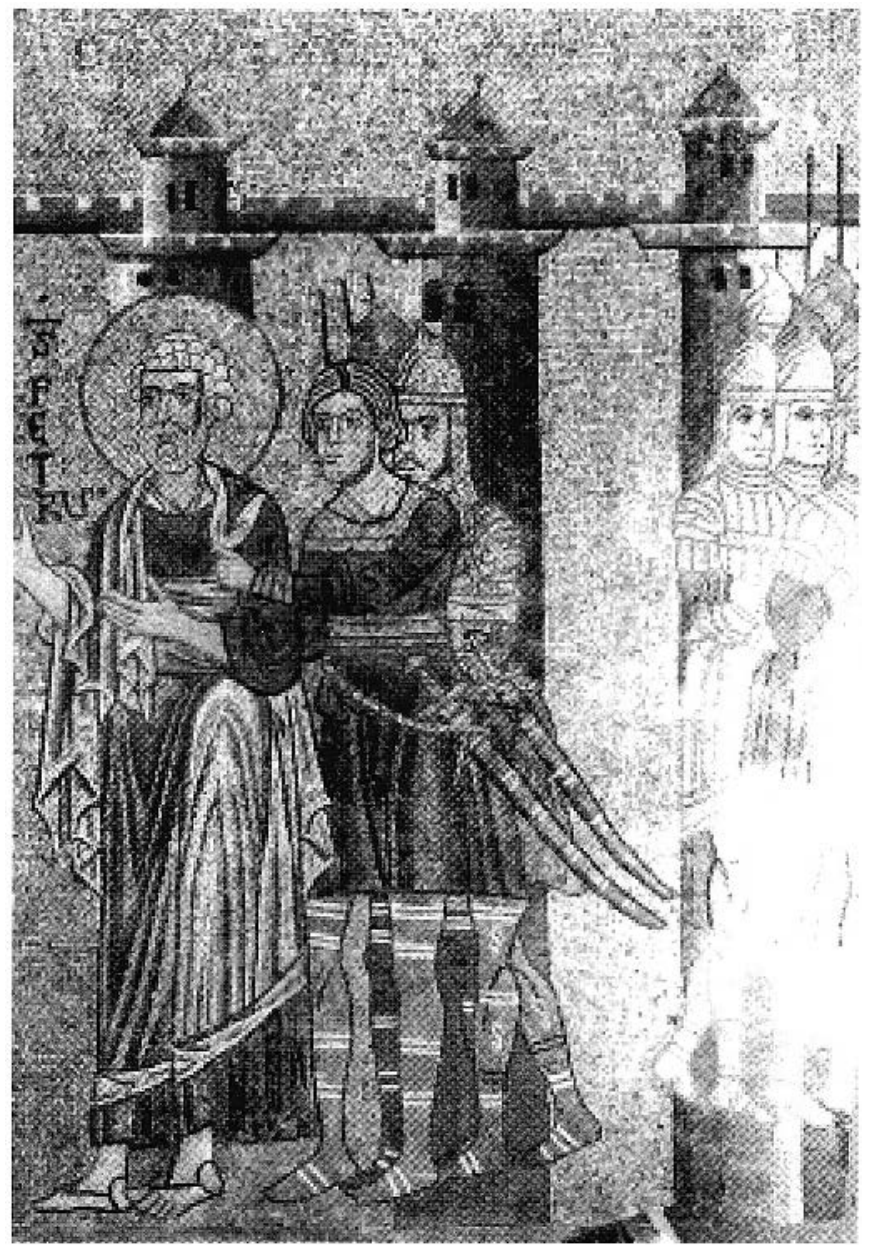

against an arcade to give the sense of a church interior, and it shows Clement celebrating Mass at the altar with the aid of two deacons (fig. 3). In the centre of the composition, Sisinnius walks away from the altar, holding two children by the hands. ${ }^{10}$ Theodora stands on the far right with her hands raised in prayer. The inscription above, which was completely reset in the nineteenth century, reads: SISINNIVS SACRATA SCRVTANS SIBI IVRE NEGATA; NON VIDET ABSQVE MORA SVRDVS; MISERET THEODORA (Sisinnius, investigating the consecrations rightfully denied to him, does not see and [becomes] deaf without delay; Theodora feels pity [for him]). As in the north choir chapel, the next scene has survived in a fragmentary state and is hidden behind the organ. It is framed by a trabeated arcade in order to indicate a different architectural space. Sisinnius stands on the right as he gestures towards Theodora, Clement, and two clerics. The young man crouching in front of Clement in the centre of the composition is a Baroque addition (fig. 4). ${ }^{1 \prime}$ The iconography of the scene is generic, but seems to represent the confrontation between Sisinnius and Clement at the house. This identification is sup- 


\section{VIGILANT EXIT.CITATISTE.}

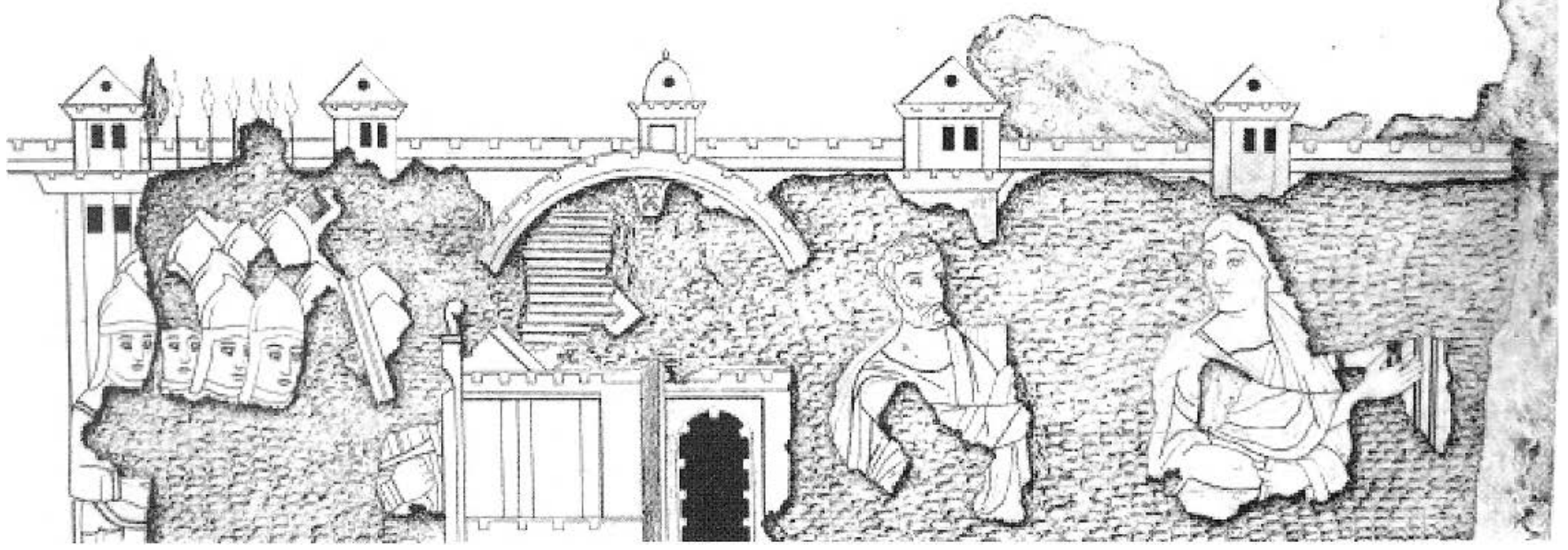

Figure 3. Saint Clement celebrates Mass, south choir chapel, Church of S. Marco, Venice (Photo: National Gallery of Art, Washington, D.C.).

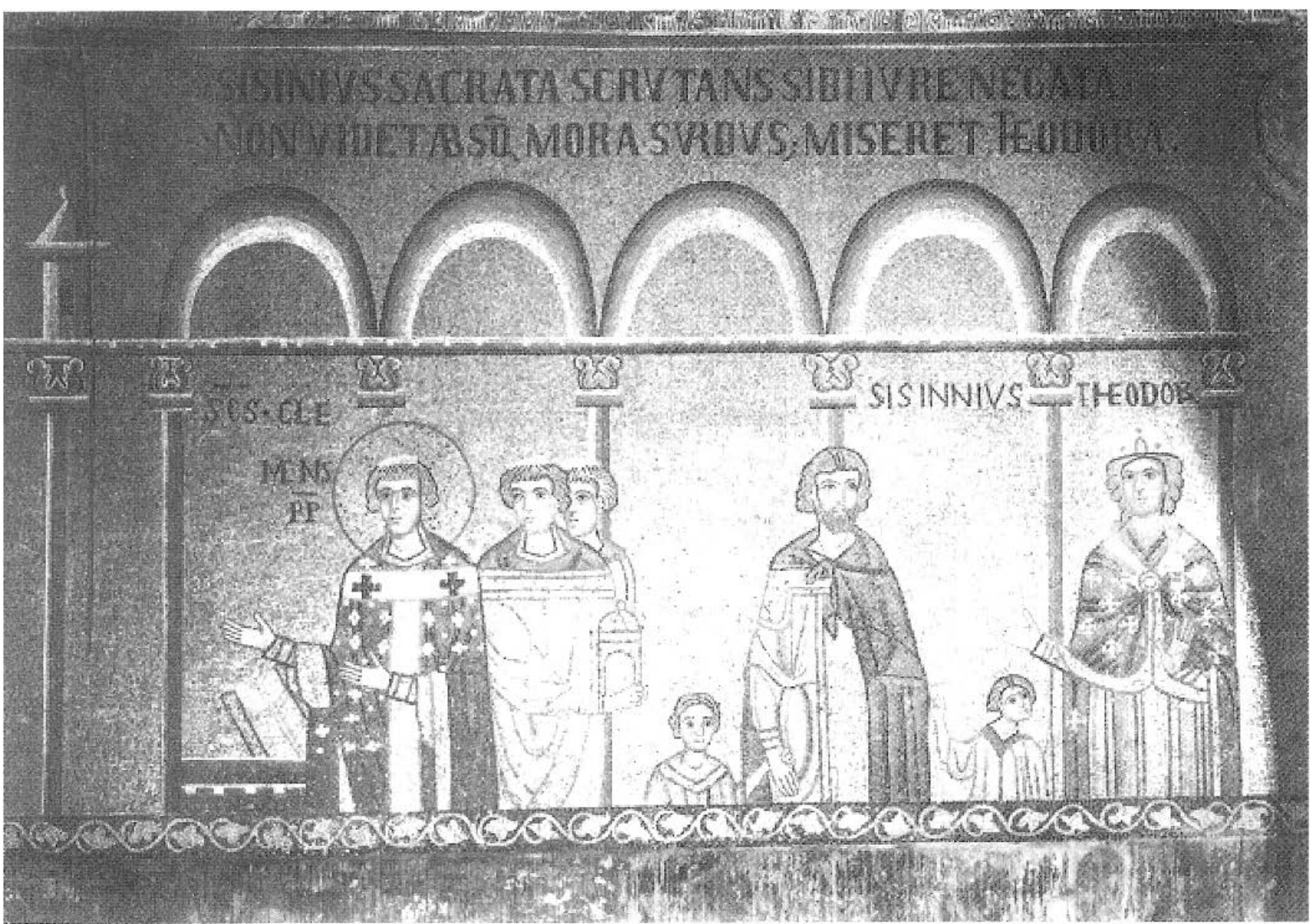



III, pl. 22).

\section{PRESV LAITCLERVMOVMVISRELGARES ERENVM: ESSE OOOS RERISQVE NECTARESAXA VIDERIT}

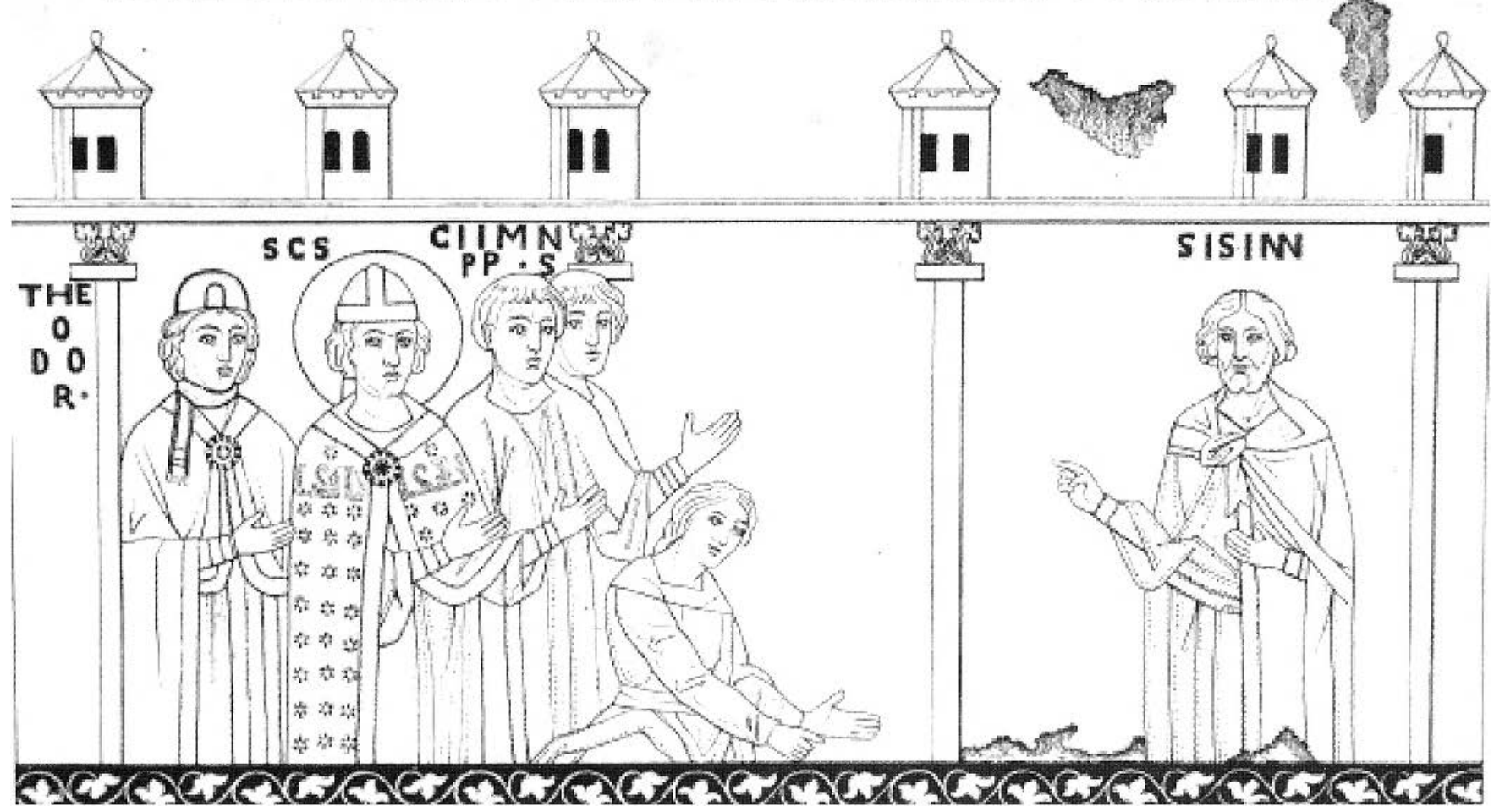

ported by the inscription above, reset in the nineteenth century: PRESVI, AIT CLERVM DVM VIS RELIGARE SERENVM; ESSE DEOS RERIS QVE NECTERE SAXA VIDERIS (the prelate says "while you wish to tie up the noble clergy, you are seen fastening together stones that you think are gods"). Although the inscription refers to the tying up of Clement, that actual moment is not shown. It may have been portrayed on the lower portion of the wall, in the space now occupied by the vegetal border.

It is difficult to be specific regarding the date of the mosaics in the choir chapcls, due to the lack of objective criteria. A probable terminus post quem is provided by the fact that the mosaics show no signs of restorations necessitated by the fire that spread to San Marco from the church of Santi Apostoli in 1106.12 In addition, the mosaics were probably completed before the addition of the marble panels on the ground floor, which an inscription on the south wall of the Cappella di San Clemente states were added by Master Petrus in $1159 .^{13}$ Following his analysis of the mosaics' style, Demus suggested that the images of Saints Peter, Clement, and Mark were most likely produced in the first quarter of the twelfth century. ${ }^{14}$ This date was supported by Rudolph Kloos, whose examination of the palaeography of the inscriptions pointed towards a date in the second or third decade of the twelfth century. ${ }^{15}$ On the other hand, in his study of the medieval cycles of Saint Mark, Tom Dale has argued convincingly that the iconography of the Marcian cycles in the vaults can be linked to the struggle for primacy in the North Adriatic in the mid-twelfth century and that they were probably produced between the years 1155 and $1159 .^{16}$ There is, however, no obvious connection between this struggle and the scenes of Saints Peter and Clement on the walls below. Thus, the question arises as to whether the mosaics of Saints Mark, Peter, and Clement are contemporary.

Demus believed that the decoration of the choir chapels was designed as a unit and that, following their usual working pattern, the mosaicists started in the vaults and moved downwards. He also believed that the work in the north choir chapel slightly predated that in the south as, for example, silver is used in large quantities in the north choir chapel, but sparingly in the south. ${ }^{17}$ Unfortunately, church building and decoration was not always undertaken in such a highly organized fashion. In the twelfth century, Abbot Suger began his restoration of the abbey church of Saint Ienis by renewing the western façade, and then moved to the east end of the church. At the time of his death 
Figure 5. Interior towards south-west, south choir chapel, Church of S. Marco, Venice (Photo: Osvaldo Böhm).

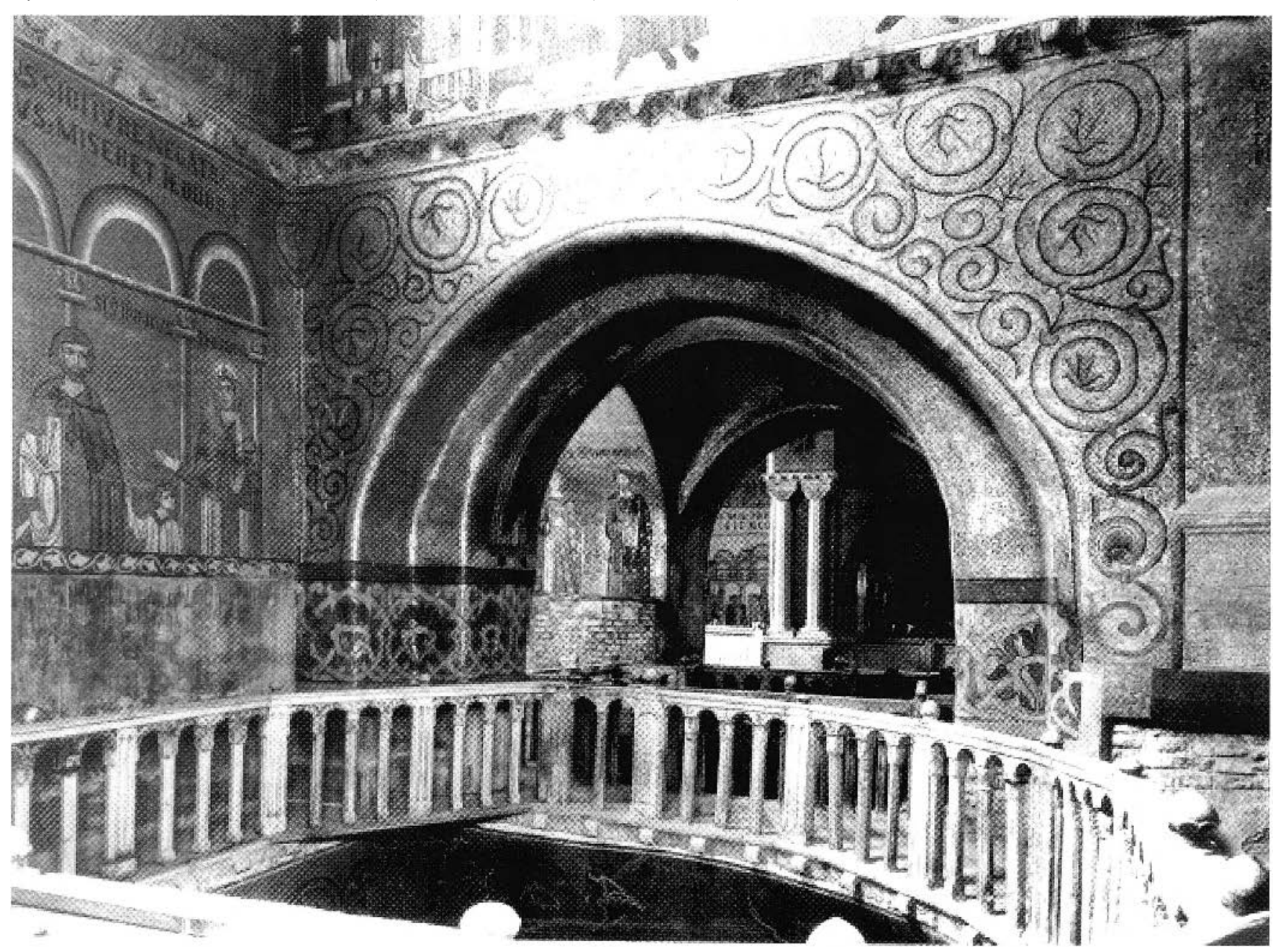

very little work on the nave had been done. ${ }^{18}$ In the fourteenth century, mosaicists working on the façade of Orvieto Cathedral started at the bottom and worked upwards. ${ }^{19}$ In other words, there may be exceptions to normal working practices. In the choir chapels of San Marco, a marble cornice creates a distinct separation between the mosaics on the walls and those in the vaults (fig. 5). It seems likely, therefore, that the two groups of mosaics were produced at separate times. Indeed, just as the Marcian cycles can be linked to historical events in the midtwelfth century, I propose that the mosaics of Saints Peter and Clement can be linked to events in the second quarter of the twelfth century and that they were produced between the years 1125-29.

In dedicating the choir chapels to Saints Peter and Clement, the Venetians intended to portray the saints as a pair. In selecting Peter, the Venetians chose a saint who was closely linked to Mark: both were apostles, both were together in Rome and, according to the legends that were circulating in the North Adriatic in the twelfth century, Mark evangelized Aquileia at Peter's request. ${ }^{20}$ By contrast, the choice of Clement as the titular saint of the south choir chapel is unusual, since Peter is more typically coupled with Paul. From the early years of Christianity Peter and Paul were both applauded as outstanding heroes of the faith, and the idea that they had met in Rome and had worked together to establish Christianity in the city became part of church propaganda in the second half of the fourth century. ${ }^{21}$ In the final decades of the fourth century, when work began to rebuild the modest funerary church of San Paolo fuori le mura, the new church imitated Saint Peter's closely in size, plan, and decoration, making a public statement that reinforced the equality of the two apostles. ${ }^{22}$ Saint Peter's had a profound influence on western medieval art and architecture. ${ }^{23} \mathrm{Although}$ we cannot be certain of how its apse was adorned in the early Christian period, the copies it generated indicate that it was 
probably a variant of the thirteenth-century mosaics that showed an enthroned Christ flanked by Peter and Paul, palm trees, and a procession of lambs towards the Agnus Dei below. ${ }^{24}$ Indeed, the format of Christ flanked by Saints Peter and Paul became a standard type of apse decoration throughout the Middle Ages. An adaptation of this grouping, and one that forms an interesting comparison to the church of San Marco, appears in the twelfth-century mosaic decoration of the cathedral of Monreale in Sicily. In Monreale, an image of Christ Pantocrator fills the conch of the apse, and the stories of Saints Peter and Paul adorn the south and north choir chapels respectively. 25

Why, therefore, is Peter paired with Clement in the church of San Marco? In the Middle Ages, the veneration of saints was closely linked to the presence of their relics, and an eleventhcentury inscription states that the relics of Clement were among those stored in the altar of the south choir chapel. ${ }^{26}$ It is also likely that the Venetians acquired Clement's relics as early as the ninth century, when Constantine and Methodius, who had discovered Clement's relics at Cherson in the Crimea, stopped off in Venice on their way to Rome. ${ }^{27}$ Nevertheless, the altar contains not only the relics of Clement, but also those of ten other saints, some who have close ties to the Venetian lagoon. ${ }^{28}$ The presence of Clement's relics does not, therefore, fully explain the veneration of him in the south choir chapel. In the eleventh century, the commemoration of Clement's feast day was recorded in a Venetian saints' calendar, ${ }^{29}$ and by the twelfth century there was definitely an increased interest in Clement's cult. In addition to the mosaics of him placed in the south choir chapel, the mosaics of the south dome, produced between the years 1120-25, included his image alongside those of Saints Nicholas, Blaise, and Leonard. ${ }^{30}$ In 1141 a church dedicated to Clement, complete with a hospital, was built on an island in the lagoon to serve pilgrims from the Holy Land. ${ }^{31}$ By the late thirteenth century, the dogaressa provided a meal for the clerics of San Marco on Clement's feast day, ${ }^{32}$ and in the fourteenth century this celebration was referred to as the festival of the dogaressa. ${ }^{33}$ As mosaics of Clement appear in the south dome and the south choir chapel at approximately the same time, on the side of the church associated with the doge, and the later evidence confirms a link between Clement's cult and the dogaressa, the connections between Clement's cult, the doge, and the dogaressa are compelling. They do not, however, explain the partnership of Peter and Clement in the choir chapels.

Bruno Bertoli believed that Clement's inclusion was linked to his role as Peter's successor and to his Egyptian connections. ${ }^{34}$ He cited the Pseudo-Clementine literature, a group of apocryphal texts attributed to Clement that were written in the first half of the third century. The Clementine Recognitions and Homilies describe a similar series of events: Clement's travels in the East, his meeting with Peter, the conflict with Simon Magus, and Clement's reunion with his family. In the Homilies Clement discusses his journey from Rome to Judea, his conversion during a side trip to Alexandria, and his meeting with Peter in Caesarea, at which time Peter asked Clement to join him on his travels to Rome. ${ }^{35}$ In the Recognitions, however, Clement states that he converted to the faith in Rome and makes no mention of stopping off in Alexandria on his way to Judea. ${ }^{36}$ Without denying Clement's Egyptian connections, I believe the key to understanding the partnership of Peter and Clement in San Marco lies in the belief, described in Clement's letter to James, that Peter designated Clement as his successor. ${ }^{37}$

The Venetian preoccupation with succession is clearly expressed in the mosaic decoration of the choir. Peter's role in sending Mark to preach in Aquileia, work that was continued by Hermagoras following Mark's departure, is emphasized in the apse mosaics that show Peter presenting the gospel to Mark who, in turn, presents it to Hermagoras. ${ }^{38}$ In addition, in the vault of the north choir chapel, Peter's consecration of Mark lies directly above that of Peter consecrating Hermagoras, and Mark baptizing the leper Athaulf in Aquileia sits above a scene of Hermagoras baptizing in Aquileia. ${ }^{39}$ On the opposite side of the vault, Mark heals the shoemaker Anianus, his successor in Alexandria. ${ }^{40}$ Through the choice of scenes and their arrangement, the iconography of the north choir chapel focuses on succession, in a way that makes reference to topical events and Venice's role in usurping the importance of both Aquileia and Grado. Thus, while Venice's acquisition of Mark's relics in the ninth century was clearly an act of self-promotion, in the twelfth century the city justified its actions by promoting itself as the rightful successor to both Aquileia and Grado. ${ }^{41}$

The Venetians were concerned with their place in world history, and were aware that their city lacked a connection with the antique past. They compensated by creating links, some real and some imagined. In the ninth century they established a relationship with the age of the apostles by obtaining the relics of Mark, and by the thirteenth century they were even promoting the idea that their ancestry traced back to Troy. ${ }^{42}$ When we consider the choice of Peter's partner in the context of the Venetians' concern with antiquity and succession, it makes sense that Peter's partner would be his successor to the papal throne. Confusion exists, however, over the order of the early popes who succeeded Peter. ${ }^{43}$ In the early years of the church, bishops Irenaeus of Lyons (ca. 130-ca. 200) and Eusebius of Caeserea (ca. 260-ca. 340) believed that Clement was either the third or fourth bishop of Rome, following Peter, Linus, and Anacletus, ${ }^{44}$ while Tertullian (ca. 160-ca. 225) noted that Clement had been ordained by Peter. ${ }^{45}$ In the fourth century, the Liberian Catalogue written by the so-called Chronographer of 354 , lists Clement as the third bishop of Rome (after Peter and Linus, but before Cletus), ${ }^{46}$ while Jerome (ca. 342-420), in accordance 
Figure 6. Consecration of Saint Clement, Saint Clement celebrating Mass, Attempted arrest of Saint Clement, Lower Church of S. Clemente, Rome (Photo: J. Wilpert, Römischen Mosaiken und Malereien der kirchlichen Bauten vom IV. bis XIII. Jahrhundert [Freiburg im Breisgau, 1916], IV/2, pl. 240).

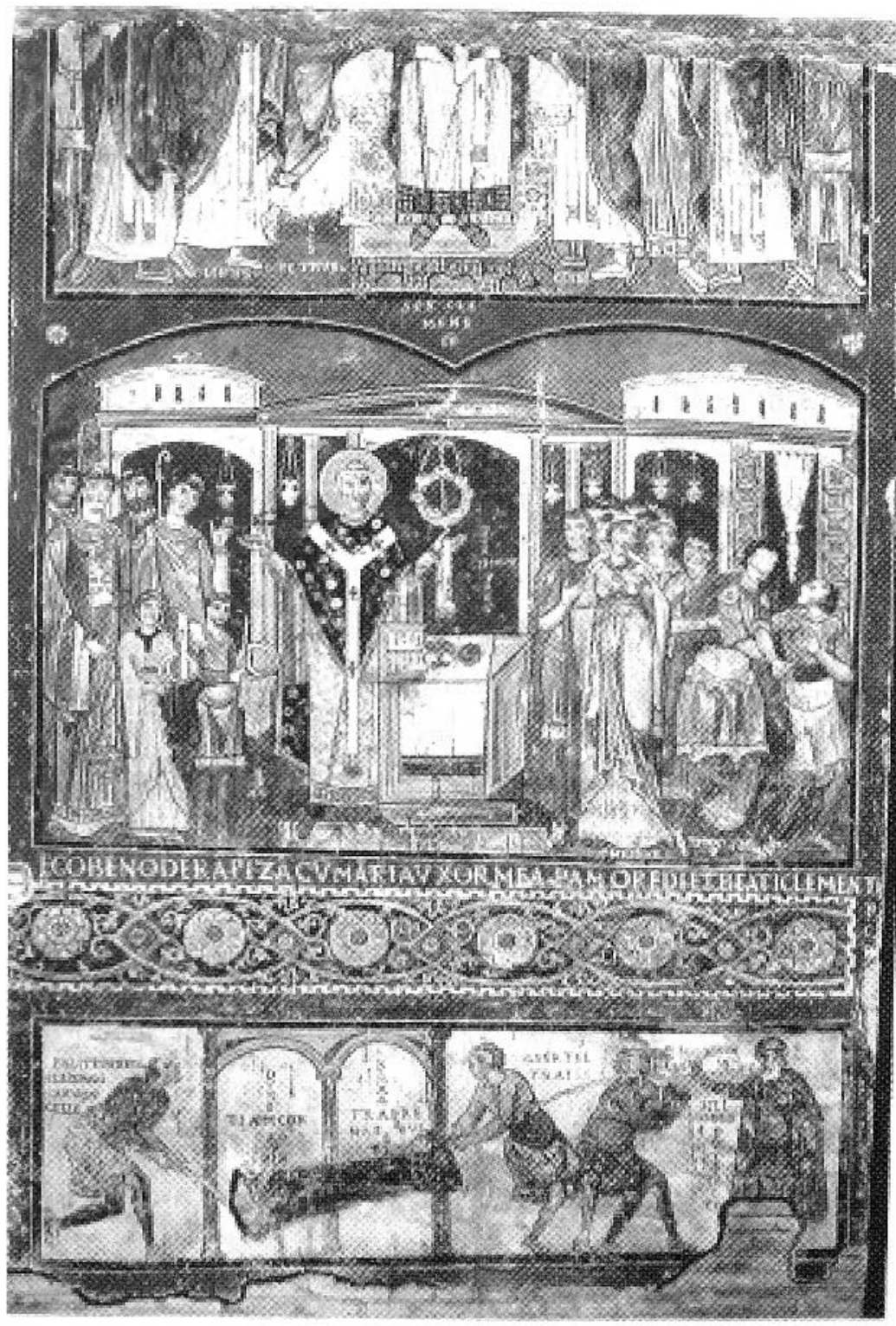

the twelfth century, resulting in the figures being cut off at knee level. Fortunately, however, the inscriptions identifying the figures are still visible. In the centre of the composition, Pope Clement is seated on a throne. He is flanked on the left by Saint Peter, who climbs a footstool at the throne's base, and by Linus and two unidentified figures. On the right, Clement is flanked by Cletus and three more unidentified figures. ${ }^{49}$ As Clement is identified as pope, and Linus and Cletus are not, the painting appears to portray the papal succession as outlined by Rufinus in the early fourth century, in the Preface to his Latin translation of the Clementine Recognitions. He explained that Linus and Cletus were bishops during Peter's lifetime, and took care of the day-to-day ministry of the church, freeing Peter to focus on his apostolic duties. ${ }^{50}$ In this way Rufinus found a solution to the confusion over the apostolic succession, one that was undoubtedly compounded by the similarity of names such as Clemens, Cletus, Anacletus, and the various forms of their abbreviations. In the middle register of the painting in San Clemente, Clement celebrates Mass. Theodora is in attendance, and on the far right, Sisinnius is being led out of the church by servants. On the dado below, Sisinnius attempts to arrest Clement, but his servants deceive him by tying up a column instead. From an iconographic standpoint, the painting in the church of San Clemente bears no resemblance to the mosaics in the church of San Marco, although the similarity of the subject matter is remarkable. The papal succession, which is implied in San Marco, is clearly outlined in the lower church of San Clemente. Furthermore, the apse mosaics in the upper church, produced during the papacy of Paschal II (1099-1118), also affirm the close bond

with his friend Rufinus (ca. 345-410), the translator of the Pseudo-Clementine Homilies and Recognitions, believed that Clement was Peter's immediate successor. ${ }^{47}$

By the late eleventh century, the belief that Clement was the second bishop of Rome is clearly expressed in a wall painting, located on a pilaster on the left side of the nave, in the lower church of San Clemente, at Rome (fig. 6). Indeed, the painting compares closely to the mosaics in the church of San Marco, as both groups of images focus on Clement's importance as Peter's successor, and both depict the story of Sisinnius and Theodora, a subject rarely portrayed in medieval art. ${ }^{48}$ The painting in the lower church of San Clemente consists of three registers. The top register was damaged during the building of the upper church in between Peter and Clement. In the conch of the apse, the Crucifixion is dominated by an elaborate vine scroll, and on the sides of the surrounding arch, Peter is seated with Clement on the right, while Paul is seated with Saint Lawrence on the left. ${ }^{51}$

The painting of Clement in the lower church and the apse mosaics in the upper church were produced during a period known as the Gregorian Reform. ${ }^{52}$ Named after its most notable advocate, Pope Gregory VII (1021-85), the Gregorian Reform movement originated in the Benedictine abbey of Cluny in the tenth century and worked towards restoring the moral fibre of the church. The reformers looked back to the simplicity of apostolic times and idealized the early Christian Roman church. Writings from the early Christian period were popular, 
including works signed or attributed to Clement, and church decoration frequently portrayed early Christian saints and revived early Christian programmes. ${ }^{53}$ The line of papal succession was also a concern, as the popes were proud of a heritage they could trace directly back to Peter. Although the work of Peter Damian, a vigorous supporter of church reform and a contemporary of Pope Gregory VII, states that Clement was the fourth bishop of Rome, ${ }^{54}$ the writings of Pope Paschal II underline the importance of Clement as Peter's successor, ${ }^{55}$ and other supporters of the Gregorian Reform, such as Bishop Bonizone of Sutri ${ }^{56}$ and Bishop Bruno of Segni, ${ }^{57}$ clearly state that Clement was Peter's successor to the papal throne.

Although modern scholarship places Clement as the third bishop of Rome after Peter ${ }^{58}$ this does not appear to have been the case in Venice in the second decade of the twelfth century. The dedication of the choir chapels to Saints Peter and Clement can be linked, therefore, to the influence of the Gregorian Reform movement and the belief that Clement was Peter's immediate successor to the papal throne. Indeed, although the mosaic work in San Marco is often viewed within the context of Byzantine art, the influence that came from Cluny - via avenues such as the Reform papacy in Rome - has been largely overlooked. For many years scholars were puzzled by the grouping of Saints Clement, Nicholas, Blaise, and Leonard in the bowl of the south dome. The problem was solved, however, when John Osborne noted that all four saints were popular during the Gregorian Reform, and suggested a reading that viewed the mosaics as promoting the Reform movement and their related crusader activities. ${ }^{59}$

In his examination of the mosaics, Demus tentatively proposed that the scenes of Saint Peter were selected due to their specifically "Petrine" nature, and also noted that the stories of Saints Peter and Clement each portrayed a foiled attempt at imprisonment. ${ }^{60}$ Bertoli linked Peter's images to Mark, and offered a reading that saw Peter returning to the Church Militant (Christians on earth) and Mark to the Church Triumphant (Christians in heaven). ${ }^{61}$ Tom Dale has proposed that the scenes of Theodora and Sisinnius in Clement's narrative were connected to the seats of the doge and the dogaressa on the ground floor of the south choir chapel, ${ }^{62}$ and Holly Hurlburt has suggested a possible analogy between the dogaressa and the images of the pious Theodora in the south choir chapel. ${ }^{63}$

These interpretations all have merit, but apply to either the mosaics of Peter, or to the mosaics of Clement, and not to the overall decorative programme. I believe the primary motivation behind the choice of scenes lies in two important details noted by Demus: first, the Peter and Clement cycles both read in a west-east direction towards the apse; and second, each cycle terminates in a foiled attempt at imprisonment. ${ }^{64}$ In the north choir chapel the narrative reads in the normal direction, from left to right, while in the south choir chapel it reads in the opposite direction, from right to left. In this way the eye of the viewer is led towards the apse and towards the image of Christ in the conch. ${ }^{65}$ Each narrative includes an image of unlawful confinement (Herod's arrest of Peter and Sisinnius's seizure of Clement) followed by an escape made possible through divine intervention. For Peter this is spelled out by the inclusion of the angel leading him out of prison, but for Clement the power of the divine is more subtle, as it is alluded to by the movement of the story towards the image of Christ in the apse.

When viewed within this context, the mosaics make an allegorical reference to the Venetian participation in the crusade of Pope Callixtus II and the Muslim capture and imprisonment of King Baldwin II. The First Crusade was preached at Clermont in 1095 and, only four years later, on July 1099, the city of Jerusalem fell. By June 1119, the Christian cause in the East suffered a serious setback in the battle known as the Field of Blood. Roger of Antioch, one of the leading Frankish princes in the Crusader States, had been killed with virtually his entire army. King Baldwin II sought aid from his relative Pope Callixtus II, and Pope Callixtus, in turn, appealed to Doge Domenico Michiel. From inside the church of San Marco, the doge rallied the Venetians to obtain their support. In August 1122, the Venetian fleet departed, commanded by the doge. As a mark of papal approval, they sailed under the vexillum of Saint Peter that had been given to them by the pope. ${ }^{66}$ Initially, the Venetians' journey to the Holy Land was leisurely. They plundered the Dalmatian coast and were besieging Byzantine Corfu when, in the spring of 1123, they were reminded of their mission by an urgent message that King Baldwin II had been captured by the Muslims. The Venetians then left Corfu and reached the coast of Palestine in May 1123. They destroyed the Egyptian fleet off the coast of Ascalon, spent Christmas in Jerusalem and Bethlehem, and then aided the Frankish army in capturing Tyre, which fell in July 1124. That same year, King Baldwin II secured his own release by paying his captors a large sum of money, and by promising to surrender Azaz and to make war on Dubais. The Venetians were not directly involved in Baldwin's release, but it was his capture that reminded the Venetians of their mission and it was following his safe release that they returned, arriving in Venice in triumph in June $1125 .{ }^{67}$

The mosaics of Saints Peter and Clement in the choir chapels of San Marco were produced in celebration of this triumph. The narrative images on the gallery walls create a link with the age of the apostles, reinforce the importance of succession, and remind viewers that, just as Peter and Clement were freed from their pagan captors through the intervention of the divine (represented by Christ in the apse), so too were the Venetians instrumental in liberating Christians in the Holy Land from Muslim control. Thus, if we consider the mosaics of 
Saints Peter and Clement within the context of the Venetian preoccupation with succession, the influence of the Gregorian Reform movement, and the Crusader fervour generated by the Reform papacy in Rome, the images no longer appear as arbitrary and unusual, but as political propaganda designed to celebrate Doge Domenico Michiel's part in the successful crusade of Pope Callixtus II. The mosaics most likely date, therefore, between the years 1125-29. ${ }^{68}$

\section{Acknowledgments}

I would like to thank Erica Dodd, Gillian Mackie, and John Osborne for their support and careful reading of the various drafts of this paper.

Notes

1 The altar in the north choir chapel contains relics of Saints Peter, John the Evangelist, Matthew, Luke, and Bartholomew. According to Otto Demus, these relics were probably acquired at the time of the church's foundation. An eleventh-century inscription states that the altar in the south choir chapel contains relics of Saints Clement, Hermagoras, Fortunatus, Cornelius, Cyprianus, Hippolytus, Cyril, Stephen, Blaise, Sergius, and Bacchus. Otto Demus, The Church of San Marco in Venice. History, Architecture, and Sculpture (Washington, D.C., 1960), 8,16-17. For the portraits of Saints Peter and Clement in the ground floor apses, see Otto Demus, The Mosaics of San Marco in Venice, I/2 (Chicago, 1984), pls $56,82$.

2 The standard works in English are Demus, The Church of San Marco and Mosaics. More recent publications on the mosaic decoration of the church include: Otto Demus et al., San Marco, basilica Patriarcale in Venezia: i mosaici, la storia, l'illuminazione (Milan, 1990); Renato Polacco, San Marco. La Basilica d'Oro (Milan, 1991); Debra Pincus, "Andrea Dandolo (1343-1354) and Visible History: The San Marco Projects," in Art and Politics in Late Medieval and Early Renaissance Italy: 1250-1500, ed. Charles M. Rosenberg (Notre Dame and London, 1990), 191-206; La Basilica di San Marco: Arte e Simbologia, ed. Bruno Bertoli (Venice, 1993); Ernst Hawkins and Liz James, "The East Dome of San Marco, Venice: a Reconsideration," Dumbarton Oaks Papers, XIVII (1994), 229-42; ' l'homas Dale, "Inventing a Sacrcd Past: Pictorial Narratives of St. Mark the Evangelist in Aquileia and Venice, ca. 1000-1300," Dumbarton Oaks Papers, XIVIII (1994), 53-104; San Marco: aspetti storici e agiografici. Atti del Convegno internazionale di studi, Venezia 26-29 aprile 1994, ed. Antonio Niero (Venice, 1996); John Osborne, "The Hagiographic Programme of the Mosaics in the South Dome of San Marco at Venice," RACAR, XXII (1995), 19-28; Penny Howell Jolly, Made in God's Image? Adam and Eve in the Genesis Mosaics of San Marco, Venice (Berkeley, 1997); Elizabeth Rodini, "Mapping Narrative at the Church of San Marco: A Study in Visual Storying," Word and Image, XIV
(1998), 387-96; Enzo De Franceschi, "I mosaici della cappella di Sant 'Isidoro nella basilica di San Marco a Venzia," Arte Veneta, 60 (2005), 6-29.

3 Demus, Mosaics, I/1, 72-83.

4 Bruno Bertoli, "Le storie di San Marco nei mosaici e le ragioni dell'agiografia," in La Basilica di San Marco, 89-124.

5 The order of Peter's successors is discussed by Louis Duchesne in the Liber Pontificalis [LP], ed. I.ouis Duchesne (Paris, 1886), I, Ixxi-lxxiii. A twelfth/thirteenth-century Venetian chronicle lists the early popes as Peter, Linus, Cletus, and Clement, Origo civitatum Italiae seu Venetiarum (Chronicon altinate et Chronicon Gradense), cd. Roberto Cessi (Rome, 1933) [=Fonti per la Storia d'Italia, LXXIII], 24.

6 Demus, Mosaics, I/1, 73.

7 For example, during the Renaissance, the porphyry statues of the four tetrarchs outside San Marco's Treasury were interpreted as representing four men who had murdered each other for a treasure. Marilyn Perry, "Saint Mark's Trophies: Legend, Superstition, and Archaeology in Renaissance Venice," Journal of the Warburg and Courtauld Institutes, XL (1977), 27-45.

8 Demus, Mosaics, I/1, 72-74.

9 Clement's Passio dates back to the fifth century and has undergone many recensions. Accounts that are relevant to the San Marco mosaics include: Ordericus Vitalis (a monk writing in Normandy in 1141) in his Historia Ecclesiastica, Patrologia Latina [PL], ed. J.P. Migne (Paris, 1844-55), CLXXXVIII, cols 197-99; "Legendae Sanctorum," Bib. Marc. cod. Lat. IX 28, fols 178-82 (for the thirteenth-century dating of this manuscript, see Suzy Marcon, Giulio Catrin, Giordana Mariani Canova, I libri di San Marco I manoscritti liturgici della basilica marciana [Venice, 1995], 103); and Jacobus de Voragine, The Golden Legend, Eng. trans., William G. Ryan, II (Princeton, 1993, repr. 1995), 323-32.

10 As Cristiana Filippini notes, the texts of the Passio alternatively refer to the servants as servi or pueri, suggesting that the mosaicists, unfamiliar with the story, were given instructions to show Sisinnius being led out by pueri, and thus depicted Sisinnius's companions as small children. "The Eleventh-Century Frescoes of Clement and Other Saints in the Basilica of San Clemente in Rome," Ph.D. diss., Johns Hopkins University, 1999, 53, n. 56.

11 Demus, Mosaics, I/1, 74.

12 Demus reports that traces of repairs following the fire appear only in the mosaics of the main apse and the main porch, Mosaics, $\mathrm{I} / 1$, 2.

13 The inscription reads: "+ ANND-M-C-L VIIII CV DVX VITALIS MICHAEL GOT .... EPIT TABVLAS PETRVS A DD ... EPIT.” For a discussion of the inscription, see Demus, Mosaics, I/1, 82.

14 Demus, Mosaics, I/1, 83.

15 Rudolph Kloos, "The Palaeography of the Inscriptions in San Marco," in Demus, Mosaics, I/1, 295-307, esp. 303.

16 Dale, "Pictorial Narratives of St. Mark," 67, 73-78.

17 Demus, Mosaics, I/1, 54-83, esp. 54, 76-77, 82.

18 Sumner McKnight Crosby, The Abbey of St. Denis (New Haven, 1942).

19 Catherine Harding, "The Production of Medieval Mosaics: the 
Orvieto evidence," Dumbarton Oaks Papers, XLIII (1989), 73 102.

20 A detailed account of Mark's mission appears in the Acts of Saints Hermagoras and Fortunatus, De S. Hermagora episcopo et Fortunato archidiacono martyribus, Acta SS., Julii III (Paris and Rome, 1867), 240-42. Ordericus Vitalis includes an abbreviated version in his Historia Ecclesiastica, cols 181-84. For the development of this legend and its sources, see Dale, "Pictorial Narratives of St. Mark," 55-59, 55, n. 8.

21 J.M. Huskinson, Concordia Apostolorum. Christian Propaganda at Rome in the Fourth Century, BAR International Series, 148()$_{\mathrm{x}-}$ ford, 1982).

22 For the building of Saint Peter's and San Paolo fuori le mura, see R. Krautheimer et al., Corpus Basilicarum Christianarum Romae, V (Vatican City, 1977), 165-279, 93-164.

23 William Tronzo, "The prestige of St. Peter's: observations on the function of monumental narrative cycles in Italy," Pictorial Narrative in Antiquity and the Middle Ages, Studies in the History of Art, XVI, National Gallery of Art (Washington, 1985), 93-112; Herbert Kessler, "'Caput et speculum omnium ecclesiarum': Old St. P'ctcr's and Church Decoration in Medieval Latium," Italian Church Decoration of the Middle Ages and the Early Renaissance, Villa Spelman Colloquia, I, ed. William Tronzo (Bologna, 1989), 119-46.

24 This mosaic is known only through watercolour copies and descriptions. See Stephan Waetzoldt, Die Kopien des 17. Jahrhunderts nach Mosaiken und Wandmalereien in Rom (Vienna and Munich, 1964), fig. 490.

25 Otto Demus, The Mosaics of Norman Sicily (London, 1949), plan 57 and pls 77-83.

26 1)cmus, The Church of San Marco, 16-17.

27 John Osborne, "Politics, diplomacy and the cult of relics in Venice and the northern Adriatic in the first half of the ninth century," Early Modern Europe, VII (1999), 369-86, esp. 381-82.

28 For example, the altar contains the relics of Saints Hermagoras, Fortunatus, Cornelius, Cyprianus, Hippolytus, and Cyrillus, all of whom are from Aquileia.

29 Silvio Tramontin, "Il 'Kalendarium' veneziano," in Culto dei Santi a Venezia, ed. Silvio Tramontin et al. (Venice, 1965), 275-327, esp. 321 .

30 Demus, Mosaics, I/2, colourplate 3; Osborne, "The South Dome of San Marco," 19-28.

31 Andrea Dandolo, Chronicon Venetum, ed. E. Pastorello (Bologna, 1938) [=Rerum Italicarum Scriptores, XII], 239; Vittorio Piva, Il patriarcato di Venezia e le sue origine, II (Venice, 1960), 118.

32 Le promissioni del doge di Venezia dalle origini alla fine del duecento, ed. Gisella Graziato (Venice, 1986), 161.

33 Bianca Betto, Il capitolo della basilica di S. Marco in Venezia: statuti e consuetudini dei primi decenni del secolo XIV (Padua, 1984), 182.

34 Bertoli, "Le storie di San Marco," 89-124, esp. 104-5.

35 "Homilia I," Patrologia Graeca [PG], ed. J.l. Migne (Paris, 185766), 11, cols 57-78.

36 "Liber I," $P G$, I, cols 1207-47.

$37 P G, \mathrm{II}$, cols 31-56, esp. cols 35, 55.

38 Demus, Mosaics, I/2, colourplate 15.
39 Demus, Mosaics, I/2, pls 38, 39.

40 Demus, Mosaics, I/2, pl. 41.

41 For a morc detailed cxamination of the relationship betwecn Saint Mark and the cities of Aquileia, Grado, and Venice, see Demus, The Church of San Marco, 30-43; and Dale, "Pictorial Narratives of St. Mark," 67-78.

42 Martino da Canal, Les estoires de Venise: Cronoca veneziana in lingua francese dalle origini al 1275, ed. Alberto Limentani, Civiltà veneziana fonti e testi, XII, l'hird Series, 3 (Florence, 1972), 6; Hugo Buchthal also notes that claims of a Trojan heritage were common to many citics in the medieval period, Historia Troiana. Studies in the History of Medieval Secular Illustration (L.ondon and Leiden, 1971), 58.

$43 L P$, I, lxxi-lxxiii.

44 Irenaeus, Contra Haereses, III, 3, PG, VII, col. 849; Euscbius, The History of the Church, trans. G.A. Williamson (Middlesex, 1965, repr. 1986), 110, 124, 208.

45 Tertullian, Liber de praescriptionibus adversus haereticos, I'L, II, col. 53.

$46 L P$, I, 2.

47 Jerome, Liber de Viris Illustribus, PL, XXIII, col. 663; Rufinus, "Praefatio ad Gaudentium cpiscopum," ${ }^{P} G$, I, cols 1205-8.

48 Filippini, "The Eleventh-C.cntury Frescocs of Clement," 51-56.

49 According to Cristiana Filippini, the destroyed part of the painting probably showed Cletus holding the gospel and Peter laying on hands, actions performed at the consecration of a new pope, "The Elcrenth-Century Frescoes of Clement," 26-46, esp. 34.

50 Rufinus, "Pracfatio ad Gaudentium episcopum," PG, I, cols 12058.

51 Stefano Riccioni, Il mosaico absidale di S. Clemente a Roma. Exemplum della chiesa riformata (Spoleto, 2006), pl. 15.

52 The literacure on the Gregorian Reform is vast. See especially: A. Flichc, Histoire de l'église depuis les origines jusquà nos jours, VII, La réforme gregorienne et la reconquête chrétienne (1057-1123) (Paris, 1940); H.E.J. Cowdrcy, The Cluniacs and the Gregorian Reform (Oxford, 1970); K. Morrison, "The Gregorian Reform," Christian Spirituality: Origins to the Twelfth Century, eds B. McGinn and J. Meyendorff (London, 1986), 177-93; C. Morris, The Papal Monarchy. The Western Church from 1050-1250 (Oxford, 1989).

53 Again, the literature on art and the Gregorian Reform is cxtensive. The most recent work is Riccioni, Il mosaico absidale di S. Clemente a Roma; see also Kirstin Norcen, "Lay Patronage and the Crcation of Papal Sanctity during the Gregorian Reform: The Case of Sant'Urbano alla Caffarella, Rome," Gesta, XL (20)()1), 39-60; and Hélène Toubert, Un art dirigé: réforme grégorienne et iconographie (Paris, 1990).

54 Peter Damian, Sermones et sanctorum historias, PL, CXLIV, col. 525: "Sicut enim beatus Petrus princeps apostolici senatus tres inter caeteros eminentiores cognoscitur habuisse discipulos, qui sibi postmodum in pontificatus arce per ordinem successerunt, primo videlicet Linus, dcindc Cletus, tertius Clemens..."

55 Paschal II, Epistola 3, PL, CLXIII, col. 32: "'Tu es Petrus, et super hanc petram aedificabo Ecclcsiam mca', et quod doctor gentium Paulus ecclesiarum omnium sollicitudincm in se habere professus 
est, hoc nobis, licet indignis, eorum vicem in Ecclesia Dei retinentibus, ab ipso $B$ Petro per Clementem concessum et credimus et confitemur"; Epistola 18, PL, CLXIII, col. 39: "Quam potestatis suac successionem ipse B. Clementi, et per eum omnibus concessit, qui eius sedi juste praesidere, e Ecclesiam Dei canonica studuerint ordinatione disponere"; Epistola 19, PL, CLXIII, col. 41: "Quam potestatis suae successionem ipse beato Clementi, et per eum omnibus transfudit, qui eius sedi juste praesidere, et Ecclesaim dei canonica studuerint ordinatione disponere."

56 Bonizone of Sutri, De sacramentis, PL, CL, col. 860: "Post beati Petri apostolorum principis inclytum martyrium quod uno eodemque die cum beato Paulo doctore gentium sub Nerone Caesare suspiciens, gloriosam Romanam fecit Ecclesiam, Clemens natione Romanus Romanum suscepit pontificatum."

57 Bruno of Segni, Tractatus, II, De sacrificio azymo, ad Leone Monachum, PL, CLXV, col. 1088: "Post ipsum beatus Clemens, cui beatus Petrus tradidit pontificatum in epistola sua ad Jacobum..."

58 For example, The Oxford Dictionary of the Christian Church, ed. F.L. Cross, second edition eds F.L. Cross and E.A. Livingstone (Oxford, 1957, repr. 1990), 299-300, states that Clement "was probably the third bishop after St. Peter, although he was often held in primitive times to have been his immediate successor."

59 Osborne, "The South Dome of San Marco," 19-28.

60 Demus, Mosaics, I/1, 72-73.

61 Bertoli, "Le storie di San Marco," 89-124, esp. 103-4.

62 "Saint Clement and the Place of the Dogaressa in San Marco in Venice," Medieval Academy Meeting (Miami, 2005). Although the medieval sources are not specific regarding the location of the doge's seat, there is a general understanding that his primary seat was in the south pulpit and that he had a second seat next to the dogaressa on the ground floor of the south choir chapcl. See Demus, The Church of San Marco, 47-50; Staale Sinding-I arsen, Christ in the Council Hall. Studies in the Religious Iconography of the Venetian Republic. Institutum Romanum Norvegiae Acta Ad Archaeologiam et Artium Historiam Pertinentia, V (Rome, 1974), 203-5; also useful, although it refers to a later period, is Andrew Hopkins, "Architecture and Infirmitas. Doge Andrea Gritti and the Chancel of San Marco," Journal of the Society of Architectural Historians, LVII (1998), 182-97.

63 Holly Hurlburt, The Dogaressa of Venice, 1200-1500 (New York, 2006) 86-87.

64 Demus, Mosaics, $\mathrm{I} / 1,73$.

65 The existing apse mosaic of Christ enthroned is a signed work by Master Petrus, 1506. We can assume, but not be certain, that it reflects the original apse decoration.

66 Andrea Dandolo, Chronica per Extensum Descripta, ed. E. Pastorello (Bologna, 1938), [=Rerum Italicarum Scriptores XII, 1], 231.

67 For the events surrounding Pope Callixtus's crusade, and the capture of King Baldwin II, see Jonathon Riley-Smith in "The Venetian Crusade of 1122-1124," I communi italiani nel regno crociato di Gerusalemme: atti del Colloquio "The Italian Communes in the Crusading Kingdom of Jerusalem," (Jerusalem, May 24-May 28, 1984), eds Benjamin Kedar and Gabriella Airaldi (Genoa, 1986), 339-50; Donald Nicol, Byzantium and Venice (Cambridge, 1988, repr. 1994), 77-81; A History of the Crusades, ed. Kenneth M. Setron (Philadelphia, 1955), I, The First Hundred Years, ed. Marshall W. Baldwin, 419-23.

68 That is, they date sometime after Doge Domenico Michiel's return to Venice in 1125 , and before his death in 1129. 